\title{
Status Report on Fast Reactor Recycle and Impact on Geologic Disposal
}

R. A. Wigeland

T. H. Bauer

E. E. Morris

April 2007

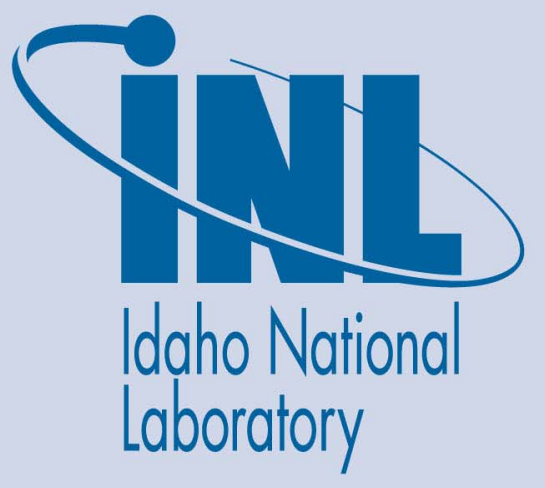

The INL is a U.S. Department of Energy National Laboratory operated by Battelle Energy Alliance 
INL/EXT-07-12531

\title{
Status Report on Fast Reactor Recycle and Impact on Geologic Disposal
}

\author{
R. A. Wigeland ${ }^{1}$ \\ T. H. Bauer ${ }^{2}$ \\ E. E. Morris ${ }^{2}$ \\ ${ }^{1}$ Idaho National Laboratory \\ ${ }^{2}$ Argonne National Laboratory \\ April 2007

\section{Idaho National Laboratory \\ Idaho Falls, Idaho 83415} \\ Prepared for the \\ U.S. Department of Energy \\ Office of Nuclear Energy \\ Under DOE Idaho Operations Office \\ Contract DE-AC07-05ID14517
}




\section{Status Report on Fast Reactor Recycle and Impact on Geologic Disposal}

R.A. Wigeland, Idaho National Laboratory

T.H. Bauer and E.E. Morris, Argonne National Laboratory

INL/EXT-07-12531 


\title{
Status Report on Fast Reactor Recycle and Impact on Geologic Disposal
}

\author{
R.A. Wigeland, Idaho National Laboratory \\ T.H. Bauer and E.E. Morris, Argonne National Laboratory
}

The GNEP program envisions continuing the use of light-water reactors (LWRs), with the addition of processing the discharged, or spent, LWR fuel to recover actinide and fission product elements, and then recycling the actinide elements in sodium-cooled fast reactors. Previous work has established the relationship between the processing efficiencies of spent LWR fuel, as represented by spent PWR fuel, and the potential increase in repository utilization for the resulting processing waste. The purpose of this current study is to determine a similar relationship for the waste from processing spent fast reactor fuel, and then to examine the wastes from the combination of LWRs and fast reactors as would be deployed with the GNEP approach.

\section{Fast Reactor Fuel Processing}

The result of processing spent fast reactor fuel has been analyzed and compared with process waste from spent PWR fuel. The fast reactor typically operates on the fissioning of transuranic isotopes rather than fissioning U-235 as is common in LWRs, although even for LWRs, the breeding and subsequent fissioning of $\mathrm{Pu}-239$ during irradiation accounts for a significant fraction of the generated energy by the end of the irradiation cycle. The fraction of transuranic material in fast reactor uranium-based fuel is substantially higher than either the initial enrichment of LWR fuel or the transuranic content of spent LWR fuel. Although the burnup of the fast reactor fuel may be higher, in $\mathrm{GWd} / \mathrm{MT}$, the result is that spent fast reactor fuel has higher decay heat than LWR fuel on an energy-generated basis at times greater than about 35 years after processing, as shown in Figure 1, with spent fuel processed 5 years after discharge; data from Ref. 1.

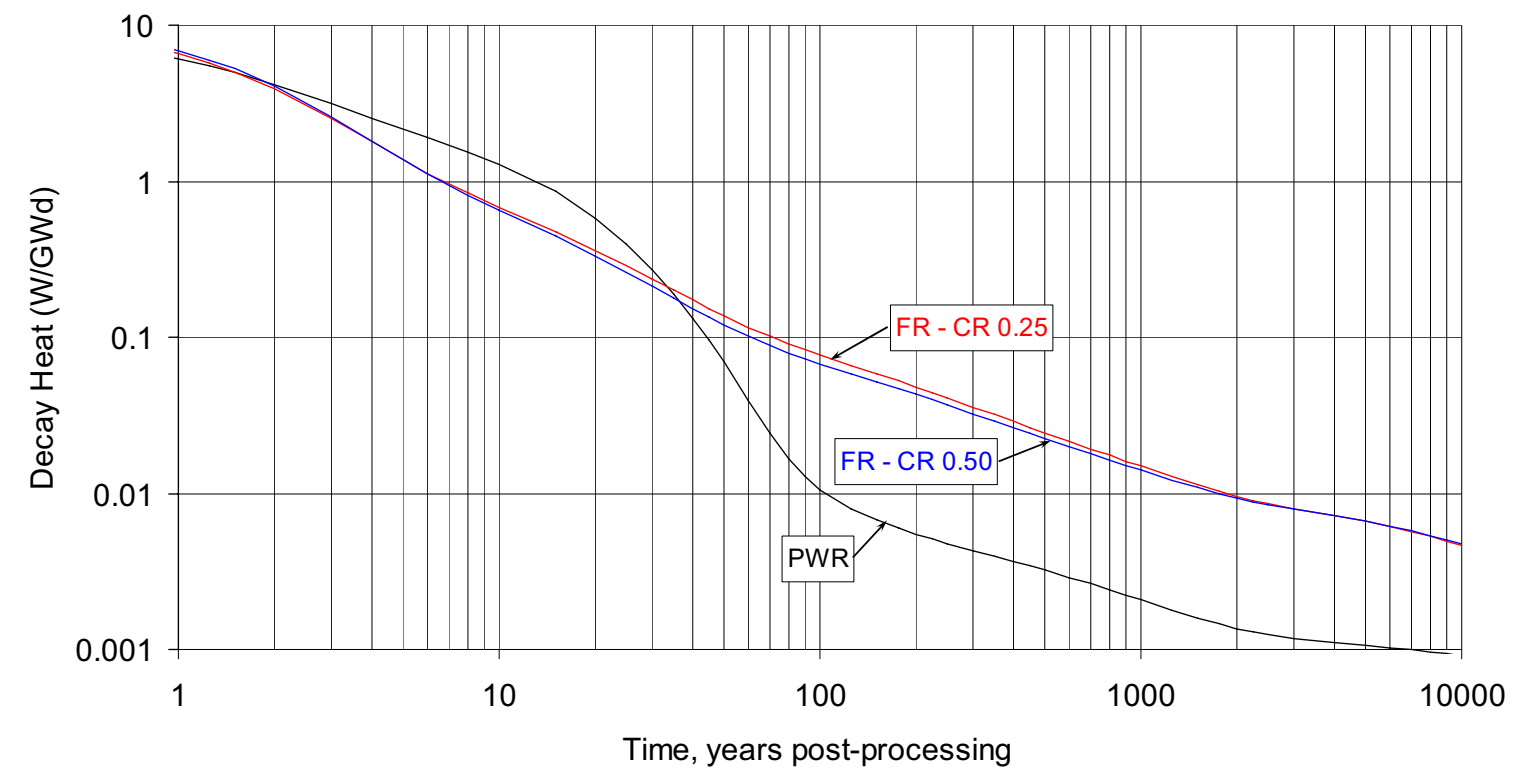

Figure 1. Process waste decay heat for spent PWR and fast reactor fuel with conversion ratios of 0.25 and $0.50,99.9 \%$ recovery of actinides, cesium, and strontium. 
For this example, the residual actinide and cesium and strontium content in the process waste is assumed to be $0.1 \%$ (99.9\% recovery efficiency). As shown in Figure 2, the fast reactor spent fuel process waste has a much higher decay heat attributable to the residual actinide content as compared to spent PWR fuel process waste. With the same assumed processing loss fraction, this reflects the much higher transuranic content of the fast reactor fuel as well as isotopic differences. Figure 3 displays the effect of the different fission product content of fast reactor spent fuel process waste with less $\mathrm{Sr}-90$ and $\mathrm{Eu}-$ 154, and more Rh-106 and Eu-155 than spent PWR fuel on an energy-generated basis.

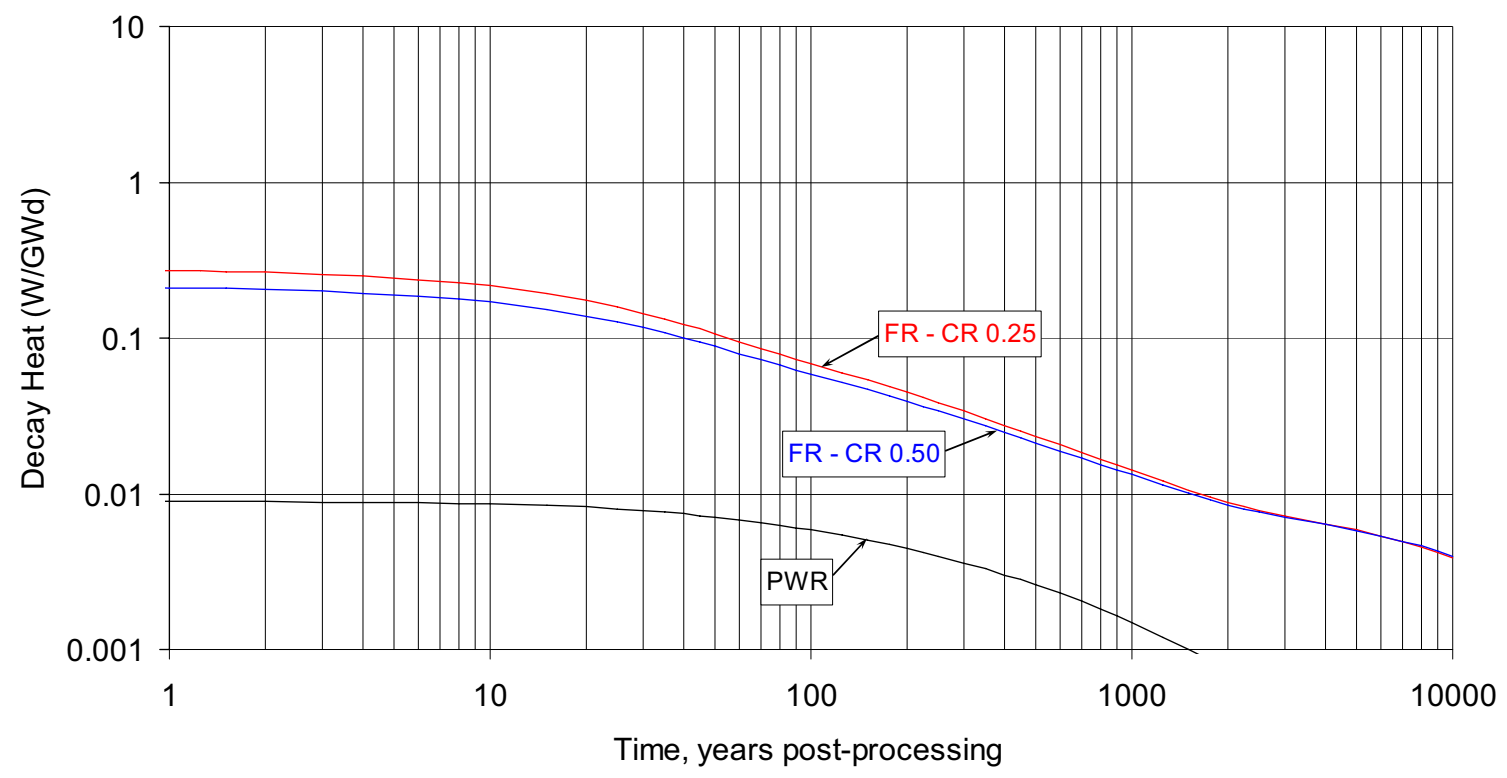

Figure 2. Process waste actinide decay heat for spent PWR and fast reactor fuel with conversion ratios of 0.25 and $0.50,99.9 \%$ recovery of actinides, cesium, and strontium.

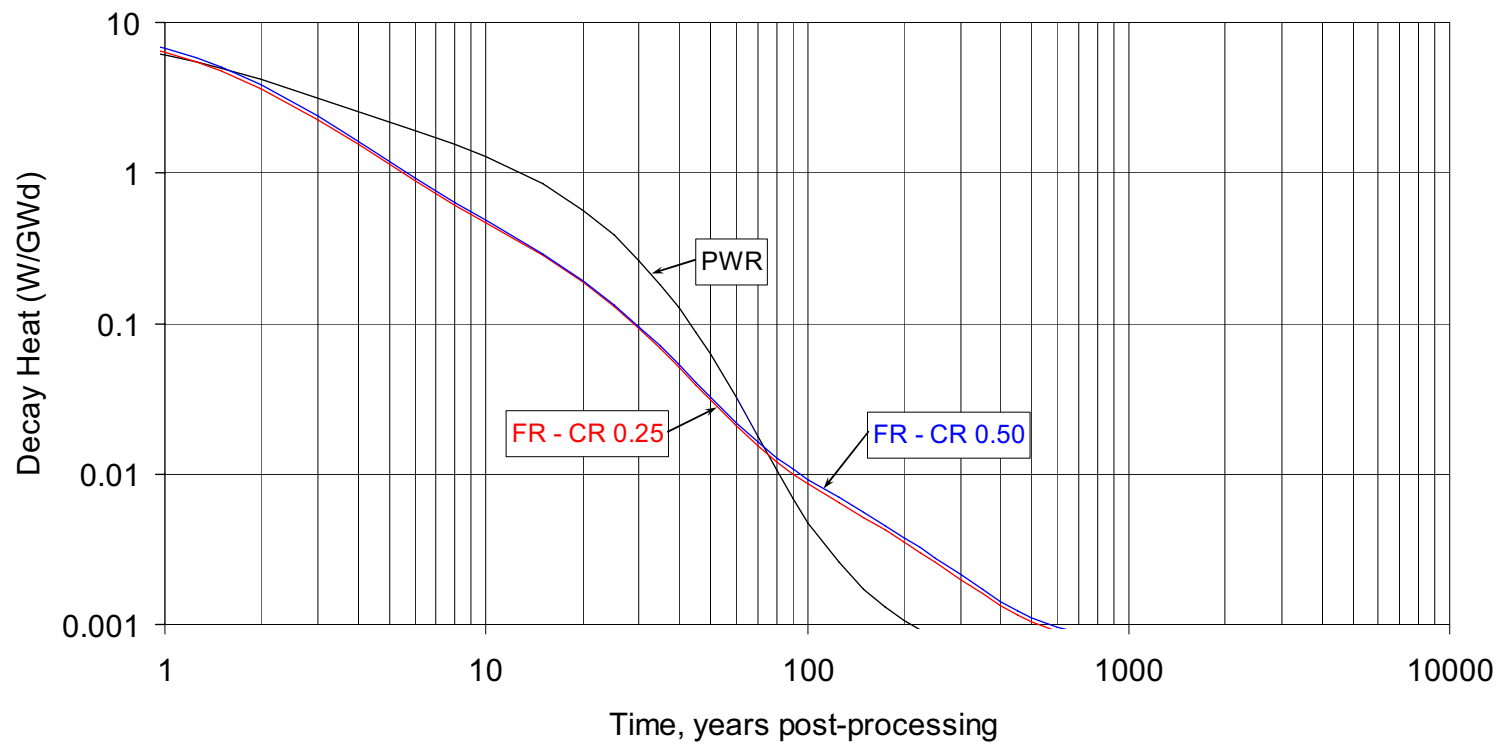

Figure 3. Process waste fission product decay heat for spent PWR and fast reactor fuel with conversion ratios of 0.25 and $0.50,99.9 \%$ recovery of actinides, cesium, and strontium. 


\section{Disposal of Fast Reactor Process Waste}

The net effect of the higher long-term decay heat for spent fast reactor fuel process waste is that the repository tunnel (drift) loading is not as high as it is for spent PWR fuel process waste, given the same level of recovery efficiency at the processing plant. The potential increase in repository drift loading is shown in Figure 4 for spent PWR fuel and process waste. The plot shows the amount of energy generated by the spent fuel or its process waste that can be stored per meter of repository drift. For example, spent PWR fuel with $50 \mathrm{GWd} / \mathrm{MT}$ burnup can be placed so that the amount of fuel that generated 55 GWd, or 1.1 MT, occupies one meter of drift length. Similarly, if $99.9 \%$ of the actinides and cesium and strontium are removed from the process waste, the process waste from spent fuel that generated $12375 \mathrm{GWd}$ can be stored per meter of drift, which corresponds to an increase in drift loading of a factor of 225 , as has been shown on previous versions of this figure [2]. This represents the waste from processing 247.5 MT of spent fuel, and with $99.9 \%$ removal, the heavy metal drift loading is $0.248 \mathrm{MT} / \mathrm{m}$ in the process waste.

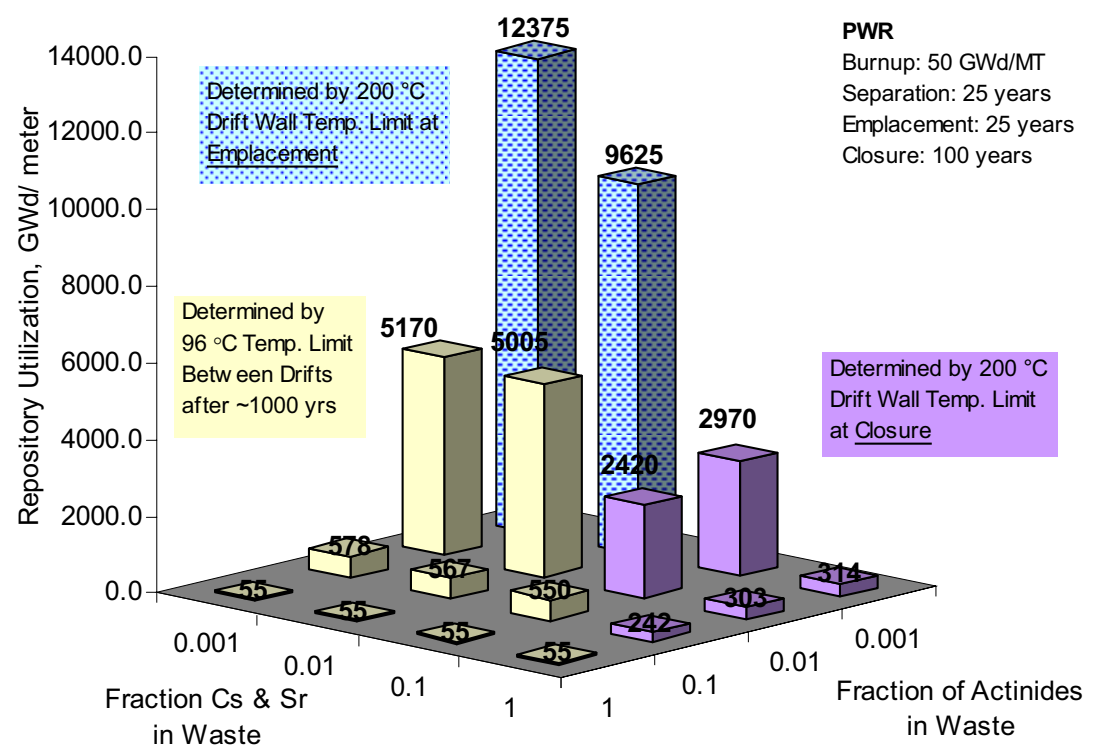

Figure 4. Increase in repository drift loading with processing and removal of actinide and fission product elements, on an energy-generated basis, for spent PWR fuel process waste.

The comparable figure for spent fast reactor fuel process waste for a fast reactor with a very low transuranic conversion ratio of 0.18 is shown in Figure 5. (All of the fast reactor neutronics analyses in this section are from Ref. 1.) Direct disposal of the spent fuel from this fast reactor could only be loaded at $2.7 \mathrm{GWd} / \mathrm{m}$, far less than the 55 $\mathrm{GWd} / \mathrm{m}$ achievable with spent PWR fuel. This is due to the much higher transuranic content of the fast reactor fuel, as discussed above. Processing and removal of the actinide elements along with cesium and strontium is effective in increasing the allowable drift loading, up to process waste from just over $2600 \mathrm{GWd}$ of spent fuel being placed per meter. While less than the $12375 \mathrm{GWd} / \mathrm{m}$ possible for spent PWR fuel, this is an increase of a factor of 965 over the direct disposal of the spent fast reactor fuel. It is also important to note that there is a much greater difference between removing $99 \%$ and 
99.9\% than for processing spent PWR fuel, since the loading in the repository is still limited by the effects of the residual actinide elements, as indicated by the limiting temperature being that between adjacent repository drifts at about 3000 years after placement. This implies that it is more important to achieve higher separation efficiency for the actinide elements when processing fast reactor fuel, again due to the higher transuranic content.

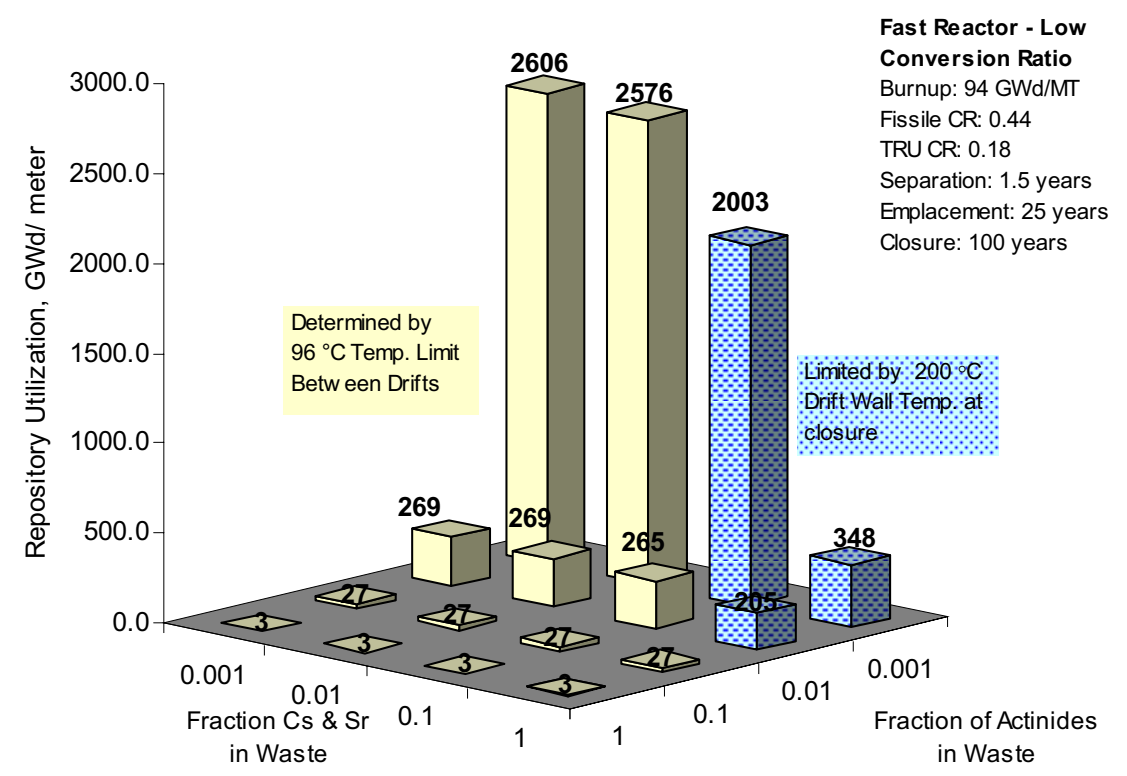

Figure 5. Increase in repository drift loading with processing and removal of actinide and fission product elements, on an energy-generated basis, for spent fast reactor fuel process waste, where the fast reactor has a transuranic conversion ratio of 0.18 .

The results for a fast reactor with a transuranic conversion ratio of 0.44 are shown in Figure 6. For this reactor, the spent fuel can be stored at $7.9 \mathrm{GWd} / \mathrm{m}$, higher than for the lower conversion ratio core, and indicative of the lower transuranic content for higher conversion ratios. With $99.9 \%$ separation of the actinide elements and cesium and strontium from the process waste, the potential drift loading for the process waste increases to waste from processing spent fuel that generated just over $7000 \mathrm{GWd}$ being stored per meter. While still not as high as the $12375 \mathrm{GWd} / \mathrm{m}$ from spent PWR fuel, this still represents an increase of a factor of 900 over the direct disposal of the spent fast reactor fuel. As with the lower conversion ratio core, there is still a substantial difference between $99 \%$ and $99.9 \%$ recovery of the actinides, since the repository loading of the process waste is limited by the residual actinide content of the process waste, indicated by the limiting temperature being that between adjacent repository drifts, occurring at about 3000 years after closure. Again, this emphasizes the need for higher separation efficiency for processing the fast reactor fuel.

Figure 7 displays the results for a fast reactor with a higher transuranic conversion ratio of 0.81 , and a fissile conversion ratio of 1.04. As with the other fast reactors, the direct disposal of spent fast reactor fuel is only $10.0 \mathrm{GWd} / \mathrm{m}$, while processing has the capability to increase this to over $8600 \mathrm{GWd} / \mathrm{m}$ for the process waste, approaching the $12375 \mathrm{GWd} / \mathrm{m}$ possible with process waste from spent PWR fuel. There is still a large 
difference between $99 \%$ and $99.9 \%$ separation efficiency for the actinide elements, and the repository drift loading is still limited by the residual actinide content in the process waste, emphasizing the need for high separation efficiency when processing spent fast reactor fuel.

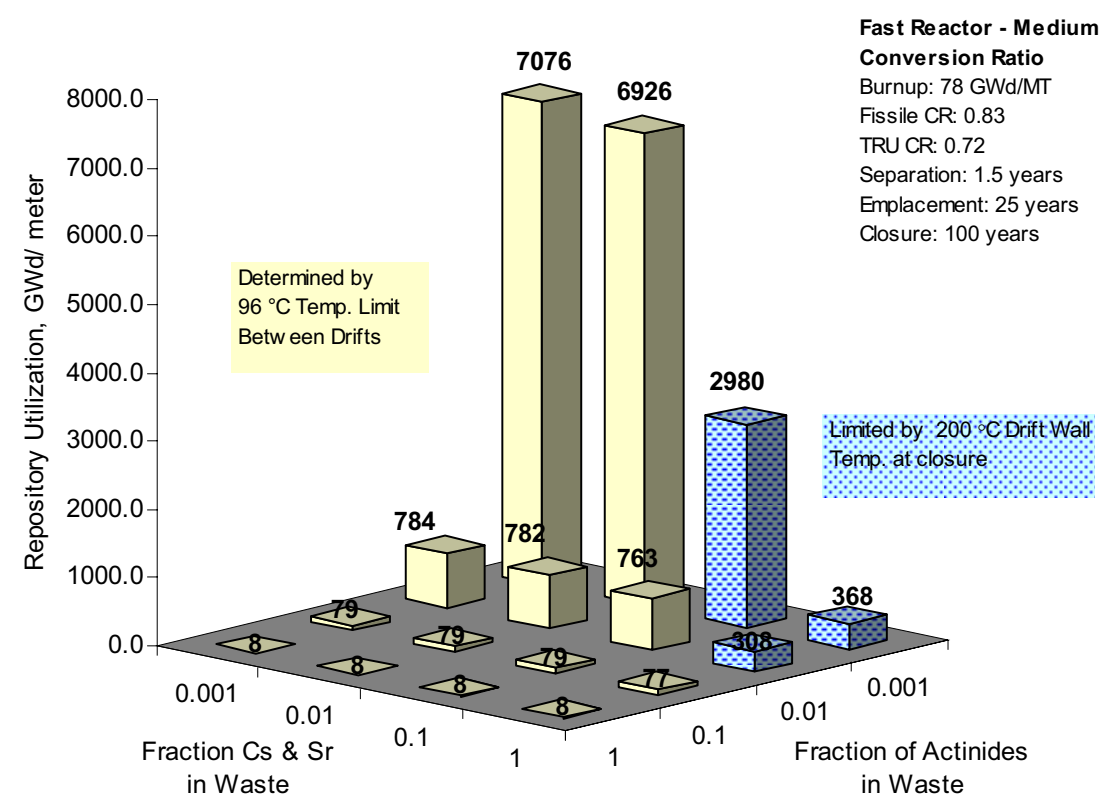

Figure 6. Increase in repository drift loading with processing and removal of actinide and fission product elements, on an energy-generated basis, for spent fast reactor fuel process waste, where the fast reactor has a transuranic conversion ratio of 0.44 .

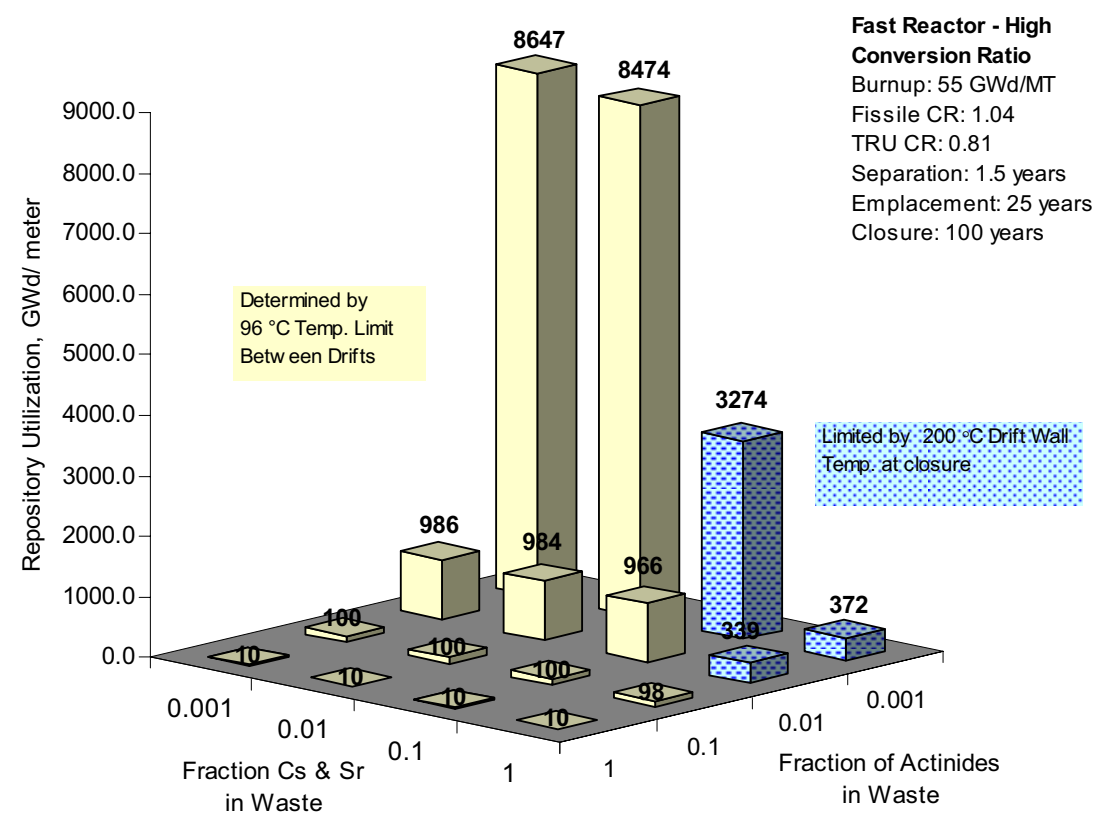

Figure 7. Increase in repository drift loading with processing and removal of actinide and fission product elements, on an energy-generated basis, for spent fast reactor fuel process waste, where the fast reactor has a transuranic conversion ratio of 0.81 . 


\section{Disposal of Process Waste from PWR and Fast Reactor Spent Fuel}

GNEP will use both LWRs and fast reactors to provide an alternate waste management approach to the 'once-through' fuel cycle currently in place in the United States. This means that process wastes from both reactor types will be placed in the geologic repository as high-level waste. The percentage of total power generation that is provided by the fast reactors is a function of the fast reactor conversion ratio, as fast reactors with lower conversion ratios can support the operation of relatively greater numbers of LWRs. In this study, the disposal of the combined process wastes from both reactor types was examined.

The first example is for a low conversion ratio fast reactor (transuranic conversion ratio of about 0.25 ), where it is estimated that about $27 \%$ of the energy would be generated by fast reactors and $73 \%$ would be from PWRs. [1] Disposal of the wastes together resulted in the overall process waste loading in the repository being waste from $13094 \mathrm{GWd}$ of spent fuel capable of being stored per meter while satisfying all thermal limits. This is about the same loading as for the PWR waste alone, and is higher than for the fast reactor waste alone. The transient thermal response of the repository is shown in Figure 8.

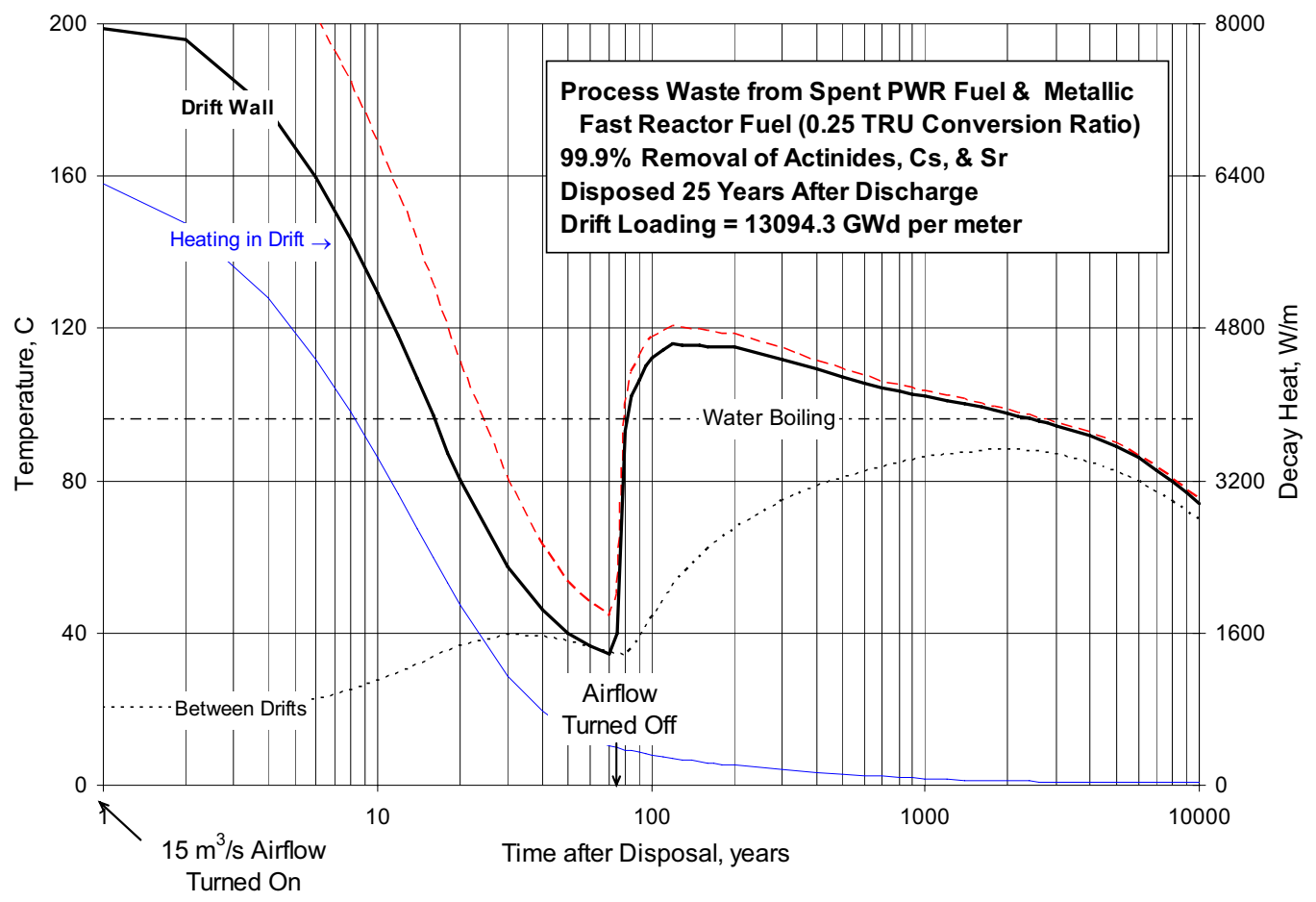

Figure 8. Transient thermal response of the repository for the combined disposal of process wastes from spent PWR fuel and spent fast reactor fuel, transuranic conversion ratio of 0.25

As seen in the figure, the limiting temperature is at the time of disposal, where the drift wall temperature approaches the limit of $200^{\circ} \mathrm{C}$. The reason for the high drift loading for the combined process wastes can be seen by examining the repository response for the process wastes individually, Figures 9 and 10. 


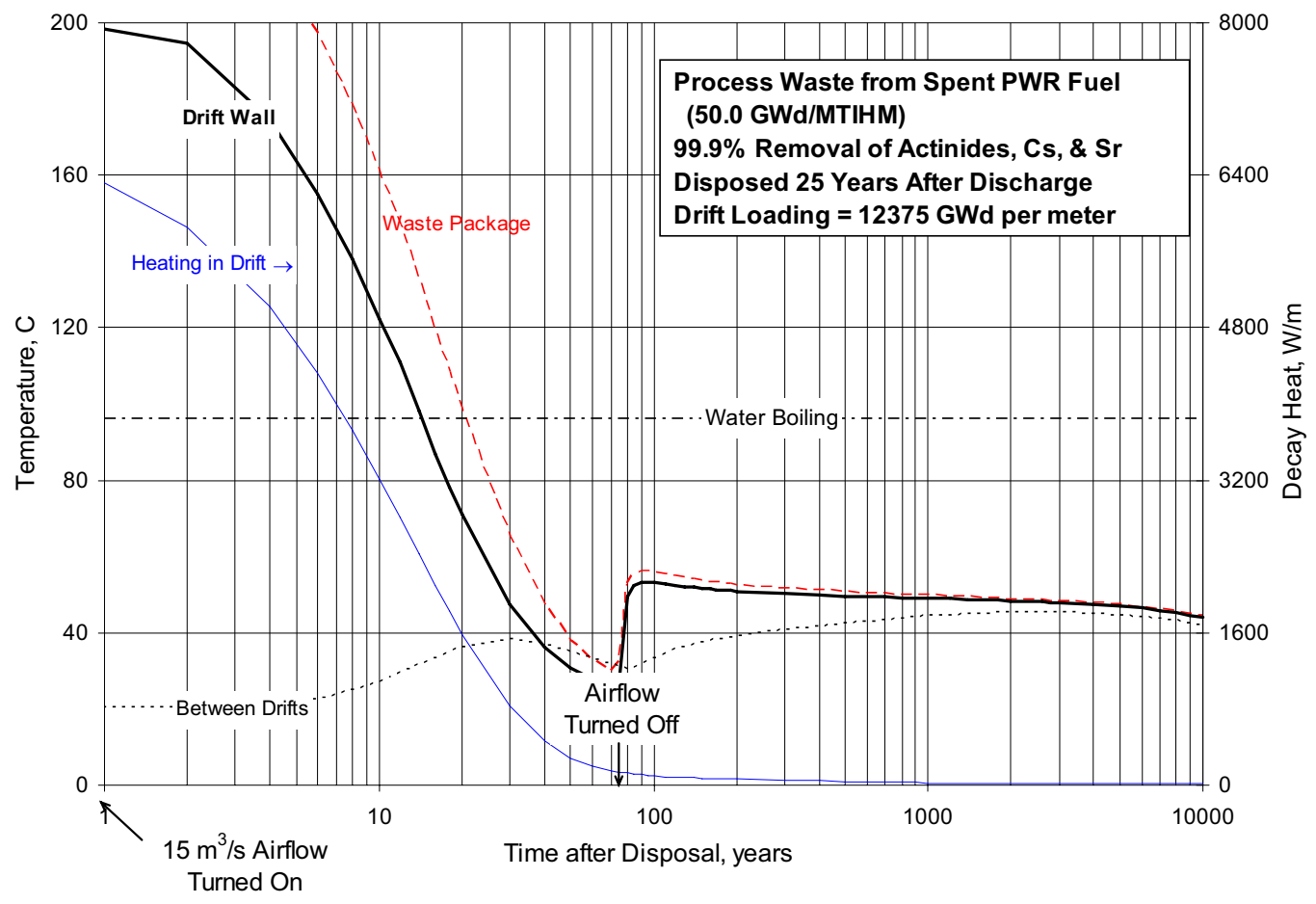

Figure 9. Transient thermal response of the repository for the disposal of process wastes from spent PWR fuel.

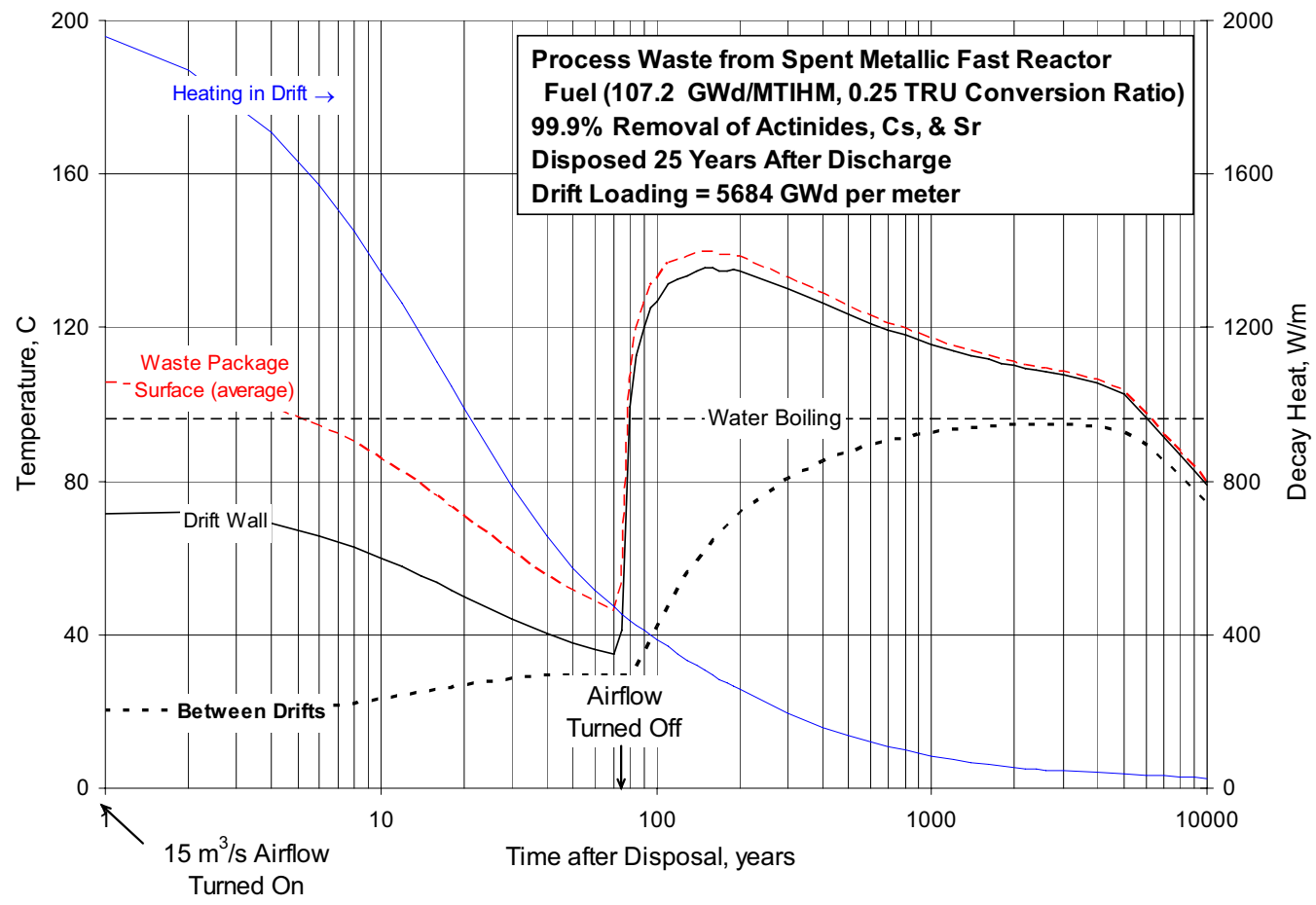

Figure 10. Transient thermal response of the repository for the disposal of process wastes from spent fast reactor fuel, transuranic conversion ratio of 0.25 . 
As shown in Figure 9, repository loading of the process waste from spent PWR fuel is limited by the drift wall temperature at the time of placement, and is controlled by the decay heat from short-lived fission products. However, for the disposal of process waste from the spent fast reactor fuel, the loading is limited by the temperature midway between adjacent drifts at about 3000 years after placement, and is the result of decay heat from the residual actinides in the process waste, as seen in Figure 10. (It should be noted that process waste loading in Figure 10 is higher than for the very low conversion ratio fast reactor results shown in Figure 5 as a result of the higher conversion ratio and higher discharge burnup in this case.) As a consequence, process waste from the spent fast reactor fuel can be placed in the same location as the process waste from spent PWR fuel, to some extent. Placement of process waste from spent fast reactor fuel adds little to the decay heat at the time of placement, while there is little contribution from the spent PWR fuel process waste to the decay heat causing the peak temperature midway between adjacent drifts. Examination of Figure 8 demonstrates that while the limiting temperature is the drift wall at the time of placement, the temperature midway between adjacent drifts peaks near the water boiling point at about 2000 years, so that loading is limited by two of the temperature limits instead of one. This effective placement of process wastes from both fuel types allows the drift loading to be as high as, or exceed, that for disposal of spent PWR fuel process waste alone.

A second case was examined for a fast reactor with a moderate transuranic conversion ratio of 0.50 . In this case, the fast reactors would provide about $37 \%$ of the power generation, while the PWRs provide the remaining 63\%.[1] Disposal of the waste forms from both fuel types together in this case resulted in a process waste loading in the repository of waste from $12950 \mathrm{GWd}$ being stored per meter, essentially the same answer as for the low conversion fast reactor case. This is the result of the process waste from the fast reactor being allowed a loading of about $6050 \mathrm{GWd} / \mathrm{m}$, which compensates for the higher fast reactor fraction in the system.

The transient thermal response of the repository is shown in Figure 11. In this case, the loading is limited by the temperature midway between adjacent drifts at about 3000 years, while the drift wall temperature at the time of placement is slightly below the limit of $200^{\circ} \mathrm{C}$. Again, the loading of the process wastes from both fuel types can be effectively placed in the same location in the repository, where the loading is limited by two of the temperature limits instead of one.

Thermal analyses for self-sufficient fast reactor (fissile conversion ratio of 1.0) resulted in a loading for the process waste of just over $10000 \mathrm{GWd} / \mathrm{m}$, indicating that the potential repository loading benefit is not a strong function of the fast reactor conversion ratio.

The overall result of this part of the study is that the use of both LWRs and fast reactors as proposed in GNEP would produce process wastes from both, and combination of the two waste streams can be used to maintain the substantial loading benefits in the repository. However, as part of this evaluation, it is also essential to consider the impact on the peak dose rate for releases from the repository, as this will ultimately be the basis on which any repository design is licensed. 


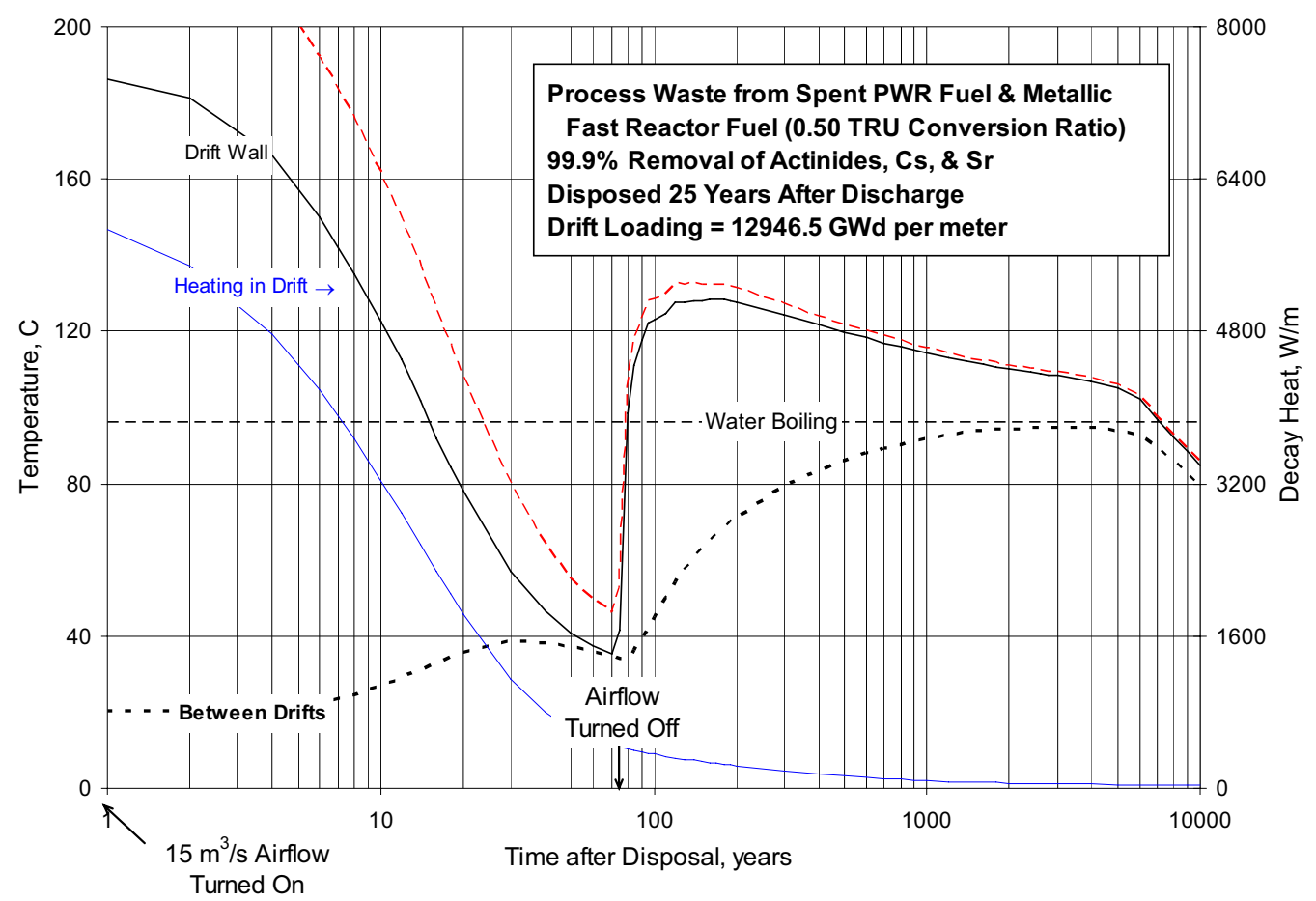

Figure 11. Transient thermal response of the repository for the disposal of process wastes from both spent PWR fuel and spent fast reactor fuel, transuranic conversion ratio of 0.50

\section{Dose Rate from Fast Reactor Process Waste}

The effect of processing on the dose rate associated with disposal of fast reactor spent fuel and the process waste has been recently reported for the Advanced Burner Test Reactor (ABTR) concept.[3] The results are summarized in Table 1.

Table 1. Comparison of Normalized Peak Dose Rates for ABTR Spent Fuel and Process Waste with Corresponding Peak Dose Rates for Spent PWR Fuel

\begin{tabular}{|c|c|c|c|c|c|c|}
\hline $\begin{array}{l}\text { Direct } \\
\text { Disposal } \\
\text { of Spent } \\
\text { PWR Fuel }\end{array}$ & $\begin{array}{l}\text { Disposal } \\
\text { of Spent } \\
\text { PWR Fuel } \\
\text { in Glass }\end{array}$ & $\begin{array}{l}\text { Direct } \\
\text { Disposal } \\
\text { of Spent } \\
\text { ABTR } \\
\text { Fuel }\end{array}$ & $\begin{array}{l}\text { ABTR } \\
\text { Process } \\
\text { Waste, } \\
90 \% \\
\text { Actinide } \\
\text { Removal }\end{array}$ & $\begin{array}{l}\text { ABTR } \\
\text { Process } \\
\text { Waste, } \\
99 \% \\
\text { Actinide } \\
\text { Removal }\end{array}$ & $\begin{array}{l}\text { ABTR } \\
\text { Process } \\
\text { Waste, } \\
99.9 \% \\
\text { Actinide } \\
\text { Removal }\end{array}$ & $\begin{array}{l}\text { ABTR } \\
\text { Process } \\
\text { Waste, } \\
99.99 \% \\
\text { Actinide } \\
\text { Removal }\end{array}$ \\
\hline & & \multicolumn{5}{|c|}{ Low Conversion Ratio } \\
\hline 1.0000 & 1.4353 & 19.7661 & 3.2179 & 0.3510 & 0.0456 & 0.0132 \\
\hline & & \multicolumn{5}{|c|}{ Medium Conversion Ratio } \\
\hline 1.0000 & 1.4353 & 7.4265 & 0.9247 & 0.1168 & 0.0208 & 0.0126 \\
\hline & & \multicolumn{5}{|c|}{ High Conversion Ratio } \\
\hline 1.0000 & 1.4353 & 3.2090 & 0.4512 & 0.0799 & 0.0191 & 0.0126 \\
\hline
\end{tabular}

The results in this table demonstrate the higher dose rate for direct disposal of spent fast reactor fuel as compared to the direct disposal of spent PWR fuel. This is due to the higher transuranic content of the fast reactor fuel. In addition, the transuranic content 
increases as the conversion ratio decreases, which is responsible for the higher peak dose rate for the lower conversion ratios. The table also shows that the reduction in peak dose rate is only a factor of 20-50 at an actinide separation efficiency of $99.9 \%$. This compares with the factor of 100 reduction in peak dose rate obtained for processing spent PWR fuel with the same actinide separation efficiency. At $99.99 \%$ actinide separation efficiency, the reduction in peak dose rate is larger, a factor of 75-80, indicating that improved actinide separation efficiency may be beneficial in processing spent fast reactor fuel. This is in contrast to the processing of spent PWR fuel, where actinide separation efficiency greater than $99.9 \%$ was not effective in reducing the peak dose rate, as the peak dose rate for the process waste was no longer controlled by the residual actinide content, but by long-lived fission products. While further analysis in this area is needed, it appears that it may be necessary to achieve higher actinide separation efficiencies when processing spent fast reactor fuel in order to obtain sufficient reductions in the peak dose rate for either dose rate reduction goals or increased repository utilization goals.

\section{Thermal Recycle Options}

For comparison with the reference GNEP approach of a combination of a single irradiation in LWRs and recycle of the recovered actinides in fast reactors, analyses were also performed for thermal recycle of the recovered actinides. This part of the study used the same recycle options as an earlier study on limited recycle. [4] In this case, rather than assume the limited thermal recycle of the earlier study, it was assumed that a finite number of thermal recycles were used prior to subsequent fast reactor recycle of the recovered actinides from the last thermal recycle.

One example is where the recovered plutonium, neptunium, and americium are recycled as MOX in a thermal reactor. The curium is either disposed after each recycle, or stored for future recycle in a fast reactor. The potential loading of process waste from processing spent PWR fuel to remove $99.9 \%$ of the actinides, cesium and strontium would be waste from fuel that generated $12917 \mathrm{GWd}$ being stored per meter of drift if the curium was stored for future use (an increase factor of about 223 in this case, since the PWR burnup is slightly higher for this part of the study and direct disposal of the spent PWR fuel can be done up to about $58 \mathrm{GWd} / \mathrm{m}$ ). If the curium was sent to disposal, the potential drift loading would be reduced to the process waste from spent PWR fuel that generated $3025 \mathrm{GWd}$ being stored per meter of drift (an increase factor of about 52). As reported in Ref. 4, the recovered plutonium, neptunium, and americium from 13.5 spent PWR fuel assemblies is required to fabricate one MOX assembly for the first recycle, indicating the amount of concentration of these actinide elements that is necessary to make the MOX fuel. (For reference, as stated above, the direct disposal of the spent PWR fuel can be $58 \mathrm{GWd} / \mathrm{m}$, while the direct disposal of the MOX assembly at the end of the first recycle can only be as high as $4.3 \mathrm{GWd} / \mathrm{m}$ ).

After irradiation, the spent MOX assembly is processed to recover the actinide elements. Considering just the process waste from the MOX assembly, the potential repository drift loading is for process waste for $145 \mathrm{GWd}$ per meter of drift if the curium is also disposed, or $4247 \mathrm{GWd}$ per meter if the curium is stored. When the process waste from the MOX 
assembly is combined with the process waste from the 13.5 spent PWR fuel assemblies, this results in an overall drift loading for the process waste of $12388 \mathrm{GWd} / \mathrm{m}$ if curium is stored (an increase factor of 214), and $1276 \mathrm{GWd} / \mathrm{m}$ if the curium is disposed (an increase factor of 22). These results are shown in Figures 12.

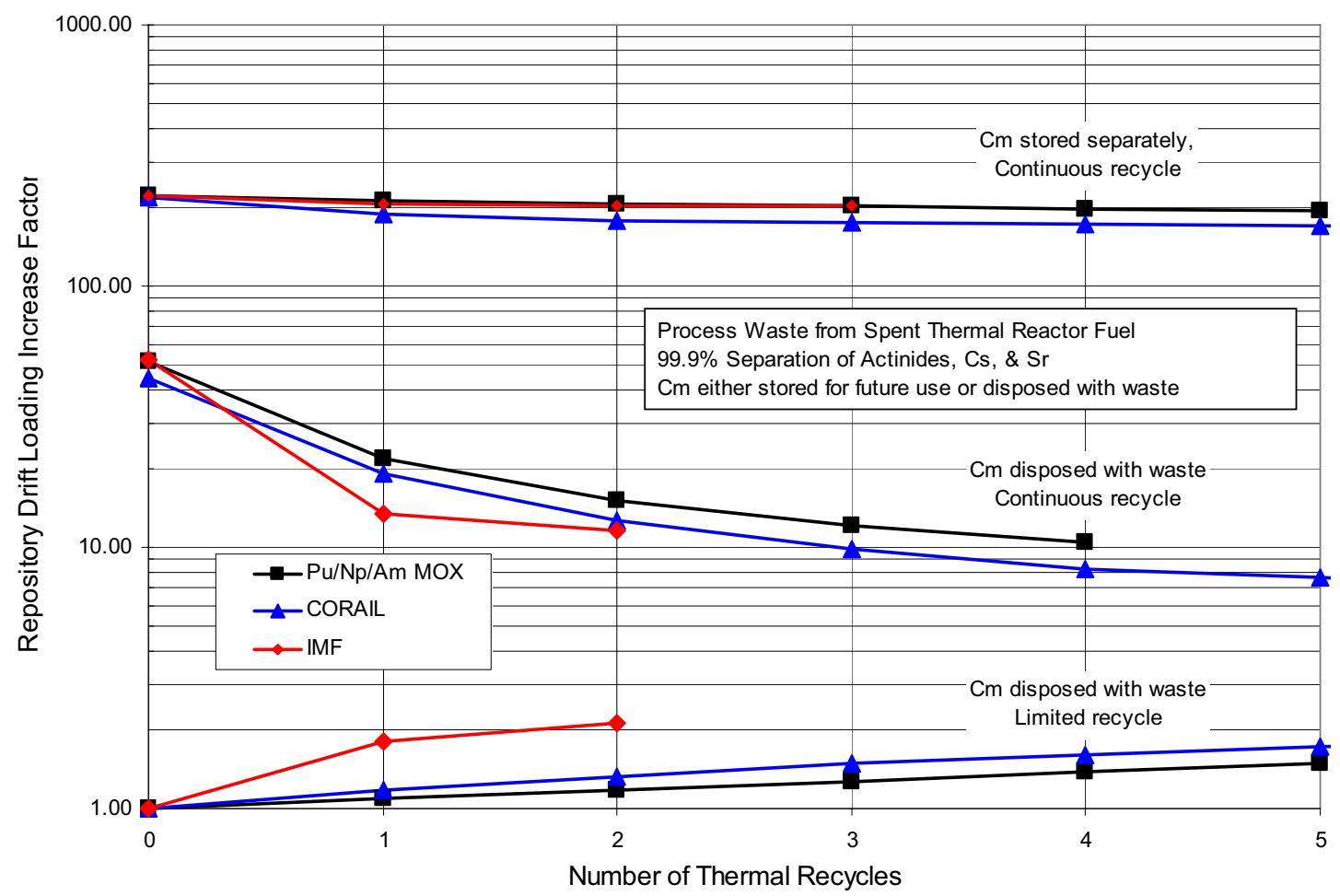

Figure 12. Repository drift loading increase factor as a function of the number of thermal recycles for MOX, CORAIL, and IMF fuel types, and for limited and continuous recycle.

Further recycles of the recovered plutonium, neptunium, and americium as MOX have been analyzed, consistent with the approach taken in the earlier study. [4] The overall trend is a decrease in the drift loading benefit to the repository as more MOX recycles in a thermal reactor are used, with the decrease being more pronounced if the curium is disposed with the waste. This is in contrast to the results for the fast reactor as discussed above, where the fast reactors in equilibrium with the PWRs yield a high drift loading benefit comparable to the initial benefit for spent PWR fuel process waste.

Similar results of decreasing benefit with increasing number of thermal recycles are obtained for the CORAIL approach, where the recycled plutonium, neptunium, and americium are used with enriched uranium fuel to support the further transmutation and fissioning of these recovered actinide elements, and for the use of IMF (inert matrix fuel), where there is no uranium content in the fuel. Further analysis is needed to quantify the impact of dose rate limitations on potential increases in repository drift loading. 


\section{Conclusions}

The impacts on geologic disposal from the use of fast reactors as part of the GNEP strategy are as follows:

1. The higher transuranic content of fast reactor fuel results in a much lower loading density in the repository for direct disposal of spent fast reactor fuel; from $2.7 \mathrm{GWd} / \mathrm{m}(0.029 \mathrm{MT} / \mathrm{m})$ for a very low conversion ratio fast reactor to $10.0 \mathrm{GWd} / \mathrm{m}(0.182 \mathrm{MT} / \mathrm{m})$ for a high conversion ratio (essentially fissile breakeven). This compares to $58.6 \mathrm{GWd} / \mathrm{m}(1.15 \mathrm{MT} / \mathrm{m})$ for spent PWR fuel.

2. Processing of the spent fast reactor fuel to remove actinides, cesium, and strontium results in large potential increases in repository drift loading for the process waste. However, unlike the process waste from spent PWR fuel, the disposal of the process waste from fast reactor fuel is still limited by the residual transuranic content of the process waste even at an actinide separation efficiency of $99.9 \%$. Process waste can be loaded in the repository at up to waste from fuel that generated $2600-10000 \mathrm{GWd}$ being stored per meter, and compares with the 12000-13000 GWd/m for disposal of process waste from spent PWR fuel.

3. Disposal of process wastes from both PWRs and fast reactors allows for increases in repository drift loading to about $13000 \mathrm{GWd} / \mathrm{m}$ in total since the disposal of process waste from spent PWR fuel is limited by decay heat at the time of placement (short-lived fission products), while disposal of the process waste from spent fast reactor fuel is limited by the integrated decay heat from the time of closure to about 3000 years after disposal (residual transuranic content).

4. Removal of actinides from the spent fast reactor fuel reduces the peak dose rate associated with the disposal of the process waste, but higher separation efficiencies are required as compared to the processing of spent PWR fuel as a result of the higher actinide content in fast reactor fuel.

5. Recycle of the actinides in fast reactors results in greater potential increases in repository drift loading for the process waste as compared to thermal recycle. Thermal recycle also reduces the potential drift loading increase with each recycle, and the reduction is more pronounced if curium is also disposed.

\section{$\underline{\text { References }}$}

1. E.A. Hoffman, Argonne National Laboratory, personal communication, September 2006.

2. R.A. Wigeland, T.H. Bauer, T.H. Fanning, and E.E. Morris, "Separations and Transmutation Criteria to Improve Utilization of a Geologic Repository," Nuclear Technology, Vol. 154, April 2006, p. 95.

3. E.E. Morris, W.M. Nutt, and R.A. Wigeland, "Effect of Reprocessing and Recycling on the Geologic Repository Dose Rate: Status", ANL-AFCI-179, September 28, 2006.

4. R.A. Wigeland, T.H. Bauer, R.N. Hill, and J.A. Stillman, "Impact on Geologic Repository Usage from Limited Actinide Recycle in Pressurized Light Water Reactors," Journal of Nuclear Science and Technology, Vol. 44, No. 3, March 2007. 